Sains Malaysiana 48(1)(2019): 75-80

http://dx.doi.org/10.17576/jsm-2019-4801-09

\title{
Bioactivity of Lufenuron against Tribolium castaneum (Herbst) (Coleoptera: Tenebrionidae)
}

(Aktiviti Biologi Lufenuron terhadap Tribolium castaneum (Herbst) (Coleoptera: Tenebrionidae))

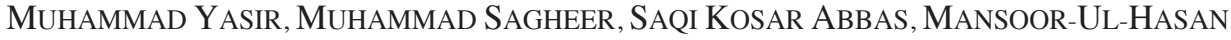 \\ SAEED AHMAD \& MUHAMMAD IJAZ*
}

\begin{abstract}
Red flour beetle, Tribolium castaneum is a serious pest of stored grain commodities. A laboratory study was conducted for evaluating the sub-lethal effects of a chitin synthesis inhibitor, lufenuron at concentrations of 0.02, 0.04 and 0.08 ppm against two strains of $\mathrm{T}$. castaneum. Lufenuron caused significant effects on larval mortality, larval duration before pupae, larval weight, pupae and adult emergence. When these adults were allowed to oviposit on untreated wheat flour, their fecundity and egg hatchability was reduced to a larger extent at all the tested concentrations as compared to control treatment. Further, subsequent development of $F_{1}$ larvae, pupae and adults were also severely prohibited. Our findings show that lufenuron can be a potential product for pest management in mills, warehouses and food storage facilities.
\end{abstract}

Keywords: Chitin synthesis inhibitor; development; lufenuron; reproduction; Tribolium castaneum

ABSTRACT

Kumbang tepung merah, Tribolium castaneum adalah perosak serius komoditi bijirin tersimpan. Suatu ujian makmal telah dijalankan bagi menilai kesan sub-maut perencat sintesis kitin, lufenuron pada kepekatan 0.02, 0.04 dan 0.08 ppm terhadap dua strain T. castaneum. Lufenuron telah menyebabkan kesan yang ketara pada kemortalan larva, tempoh larva sebelum pupa, berat larva pupa dan kemunculan dewasa. Apabila dewasa ini dibenarkan untuk oviposit pada tepung gandum tak terawat, kesuburan dan kebolehtetasan telur mereka telah dikurangkan ke tahap yang lebih besar terhadap semua kepekatan yang diuji berbanding rawatan kawalan. Di samping itu, perkembangan larva $F_{l}$, pupa dan dewasa seterusnya juga berjaya dihalang. Keputusan kami menunjukkan bahawa lufenuron boleh menjadi produk yang berpotensi untuk pengurusan haiwan perosak dalam kilang-kilang, gudang-gudang dan kemudahan penyimpanan makanan.

Kata kunci: Lufenuron; pembangunan; pembiakan; perencat sintesis kitin; Tribolium castaneum

\section{INTRODUCTION}

Widespread use of synthetic pesticides for protecting stored grain commodities possess noteworthy drawbacks including development of insecticide resistant strains (Bell 2000; Benhalima et al. 2004; Chaudhry 1997), insecticide residues on food grains (Norman 2000) and environmental and health risks to humans. Public consciousness about these threats has increased the interest for finding alternative stored-grain protectants to replace synthetic chemical insecticides (Silver 1994). One such alternative is the application of insect growth regulators which are highly effective against several pests of stored grain commodities, exhibit low mammalian toxicity and pose minimal environmental hazard as well as widely approved for use by the public (Ishaaya et al. 2007; Kostyukovsky et al. 2000; Mondal \& Parween 2001).

Chitin synthesis inhibitors (CSIs), a group of insect growth regulators, have been found to be very effective for killing immature stages of a wide variety of insect species, especially those which feed inside grains
(Daglish \& Wallbank 2005; Elek 1998a; Elek 1998b; Elek \& Longstaff 1994). Although such compounds do not mimic insect hormones, they prevent normal moulting of larval insects by inhibiting chitin synthesis (Oberlander et al. 1997). The use of CSIs has been widely observed to impair reproduction and development of insect species (Abo-Elghar et al. 2004; Arthur \& Hartzer 2018; Arthur et al. 2009; Elek 1998a; Elek 1998b; Malik et al. 2017; Parveen 2000; Parween et al. 2001; Qurban et al. 2017; Sagheer et al. 2012, 2011; Salokhe et al. 2003; Yasir et al. 2012). These compounds have been investigated for their ovicidal effects against several stored grain insects by treating either adult or the commodities in which eggs were placed (Abo-Elghar et al. 2004; Elek 1998a; Mishra et al. 2013; Parween 2003; Qurban et al. 2016; Salokhe et al. 2003; Trostanetsky \& Kostykovsky 2008; Trostanetsky et al. 2015).

Therefore, keeping in view the desirable properties of lufenuron, its effects on development and reproduction against $T$. castaneum was investigated. 


\section{MATERIALS AND METHODS}

INSECTS

Adult red flour beetle (T. castaneum) were collected from granaries of Multan and Faisalabad and these samples were designated as strains of these regions (these strains are abbreviated in the text as ML and FD, respectively). Culture of both strains was maintained for three generations in glass jars comprising of wheat flour and yeast medium placed in a cooled incubator (SANYO, MIR-254) at $30 \pm 2^{\circ} \mathrm{C}$ and $70 \pm 5$ percent relative humidity and a light duration of $12 \mathrm{~h} \mathrm{~L}: 12 \mathrm{~h} \mathrm{D}$.

\section{BIOASSAY}

Lufenuron $50 \mathrm{EC}$, an insect growth regulator, obtained from Syngenta Ltd (Pakistan), was used in this experiment at concentrations of $0.02,0.04$ and $0.08 \mathrm{ppm}$ (selected after preliminary trials) along with control treatment. A concentration of $0.08 \mathrm{ppm}$ of lufenuron was prepared in acetone to be used as stock solution and other concentrations were prepared from this stock solution. These prepared concentrations were mixed completely in wheat flour $(50 \mathrm{~g})$. Wheat flour treated with acetone alone was used as a control treatment. The culture so treated was ventilated for $24 \mathrm{~h}$ to evaporate all of the acetone from these samples. A collection of 20, fifteen-day-old T. castaneum larvae of ML and FD strains were placed separately in 100 $\mathrm{mL}$ glass jars comprising treated flour in each replicate for all the treatments. T. castaneum larvae were exposed to treated wheat flour up to pupation. The jars were kept in darkness at $28 \pm 2^{\circ} \mathrm{C}$ and $70 \pm 5$ percent relative humidity. Data regarding larval mortality was taken after 1, 3 and 5 days of treatment. Larval weight was taken at 5 th day of treatment with the help of electronic weighing balance. The data of larval duration before pupae was recorded for each individual in all the treatments. After pupation, individuals of all the treatments were shifted to untreated wheat flour under the same laboratory conditions and development of pupae and adult was recorded. The adults emerging from each treatment were allowed to feed on untreated flour for twenty days. Afterwards, adults of each treatment were placed in untreated wheat flour for 2 days for oviposition and data was recorded for number of eggs layed, hatching percentage, development of larvae, pupae and adults.

\section{STATISTICAL ANALYSIS}

Data of larval mortality was corrected using Abbott's formula (Abbott 1925) and was analyzed statistically by using Analytical software (2003) Statistix 8.1. The significant results were compared using Tukey's HSD test. The analyzed data is presented as mean \pm standard error of mean.

\section{RESULTS AND DISCUSSION}

Flour treated with $0.02,0.04$ and 0.08 ppm of lufenuron caused $1.2,5.1$ and $10.1 \%$ larval mortality in the ML strain and 1.7, 6.7 and $11.8 \%$ larval mortality in the FD strain of $T$. castaneum after 1 day of treatment (Table 1). Larval mortality was increased with increase in concentration (ANOVA, $\mathrm{df}=$ $2, \mathrm{~F}=76.87 ; p<0.001$ ), exposure period (ANOVA, $\mathrm{df}=2, \mathrm{~F}=$ 98.10; $<<0.001$ ) and was dependent on the strain (ANOVA, $\mathrm{df}=2, \mathrm{~F}=4.34 ; p<0.05$, Table 1$)$. At 0.08 ppm lufenuron, 29.8 and $32.7 \%$ larval mortality was observed in the ML and FD strains, respectively, compared to control after 5 days of treatment (Table 1). In the present experiment, lufenuron (at 0.08 ppm) caused 29.8 and $32.7 \%$ mortality in ML and FD strains of T. castaneum larvae, respectively, after 5 days of treatment. Similarly a CSI, novaluron, has been reported to cause $83 \%$ larval mortality in T. castaneum after 7 days of treatment (Kostyukovsky \& Trostanetsky 2006). Other studies also report the larvicidal activity of CSIs; triflumuron, flufenoxuron and lufenuron against T. castaneum (Parween 2003; Qurban et al. 2017; Salokhe et al. 2003).

Larval weight was reduced by 8.76 and $8.88 \%$ at 0.08 ppm for the ML and FD strains, respectively, compared to control (Figure I). This inhibition effect increased with increase in concentration (ANOVA, $\mathrm{df}=2, \mathrm{~F}=37.02 ; p<0.001$, Figure 1), but there was no significant effect of strains on percent reduction in larval weight $(\mathrm{F}=0.04 ; p>0.05$, Figure 1). Larval duration was increased significantly at all the concentrations (ANOVA, $\mathrm{df}=2, \mathrm{~F}=95.77 ; p<0.001$, Figure 2), causing 36.01 and $39.22 \%$ (at $0.08 \mathrm{ppm}$ ) increase in larval duration before pupae of ML and FD strains, respectively, compared to control treatment (Figure 2). Similarly, pupation

TABLE 1. Mean percent corrected mortality $\pm \mathrm{SE}$ of $T$. castaneum larvae exposed to flour treated with different concentrations of lufenuron at various exposure periods

\begin{tabular}{ccccc}
\hline Strain & $\begin{array}{c}\text { Concentration } \\
(\mathrm{ppm})\end{array}$ & \multicolumn{3}{c}{ Exposure period $(\mathrm{h})$} \\
\cline { 3 - 5 } & 0.08 & $10.1 \pm 1.69 \mathrm{c}$ & $22.0 \pm 1.69 \mathrm{~b}$ & $29.8 \pm 1.75 \mathrm{a}$ \\
\hline ML & 0.04 & $5.1 \pm 1.69 \mathrm{c}$ & $15.2 \pm 1.69 \mathrm{~b}$ & $22.8 \pm 1.75 \mathrm{a}$ \\
& 0.02 & $1.2 \pm 1.69 \mathrm{~b}$ & $3.4 \pm 0.00 \mathrm{ab}$ & $10.5 \pm 3.03 \mathrm{a}$ \\
& 0.08 & $11.8 \pm 1.69 \mathrm{~b}$ & $22.4 \pm 2.98 \mathrm{ab}$ & $32.7 \pm 2.98 \mathrm{a}$ \\
FD & 0.04 & $6.7 \pm 1.69 \mathrm{~b}$ & $17.2 \pm 2.98 \mathrm{ab}$ & $27.6 \pm 2.98 \mathrm{a}$ \\
& 0.02 & $1.7 \pm 1.69 \mathrm{~b}$ & $5.2 \pm 1.72 \mathrm{~b}$ & $15.5 \pm 1.72 \mathrm{a}$ \\
\hline
\end{tabular}

Means followed by same letter(s) within each row (denoted by lower-case letters) are not significantly different by Tukey's HSD test at $p=0.05$ 


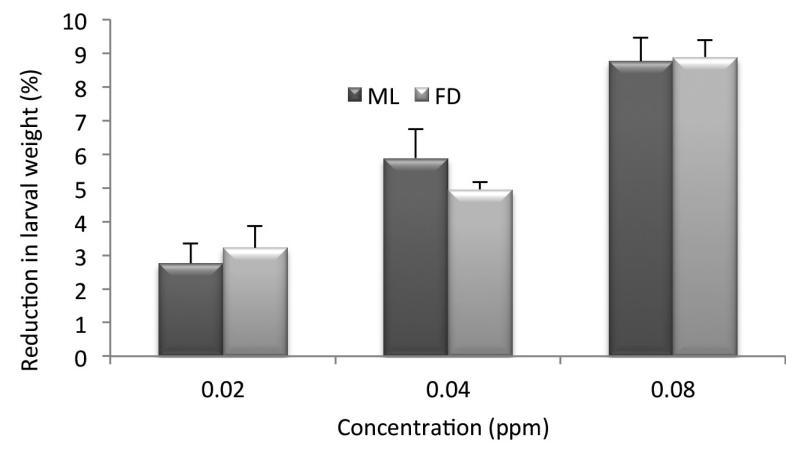

FIGURE 1. Mean percent reduction in larval weight $\pm \mathrm{SE}$ of $T$. castaneum due to exposure of larvae to various concentrations of lufenuron

from surviving larvae was seriously affected at all the concentrations tested (ANOVA, $\mathrm{df}=2, \mathrm{~F}=86.65 ; p<0.001$, Table 2). At $0.08 \mathrm{ppm}$, pupae development was inhibited by 55.8 and $58.5 \%$ in the ML and FD strains, respectively, compared to control. However, no significant differences in pupae inhibition were found due to the effect of strains (ANOVA, $\mathrm{df}=2, \mathrm{~F}=3.40 ; p>0.05$, Table 2). Emergence of adults was inhibited by 72.9 and $77.5 \%$ at $0.08 \mathrm{ppm}$ in the ML and FD strains, respectively, compared to control treatment (ANOVA, $\mathrm{df}=2, \mathrm{~F}=98.91 ; p<0.001$, Table 2). Due to feeding on lufenuron treated wheat flour, T. castaneum larval weight was found to be reduced. Several other researchers have reported that due to the effects on various physiological activities, some of the insect growth regulators decrease the body weight of insects (El-Din et al. 1990; Parveen 2000; Smagghe et al. 1996). It was assumed that flufenoxuron have caused reduction in chitin content of T. castaneum that have

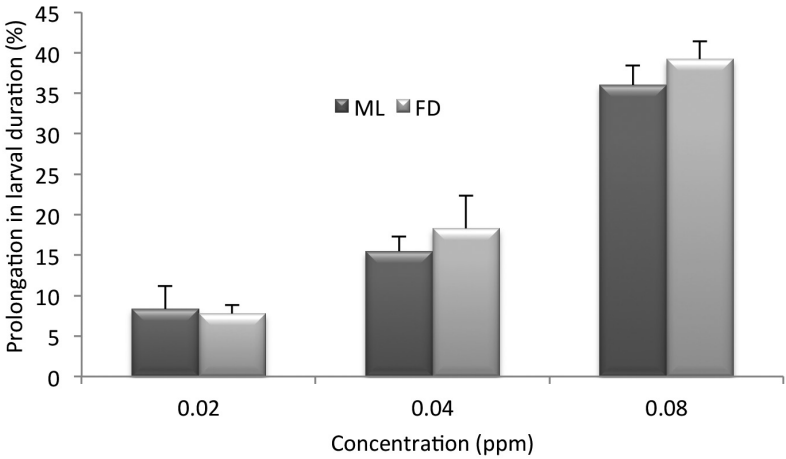

FIGURE 2. Mean percent prolongation in larval duration \pm SE of $T$. castaneum due to exposure of larvae to various concentrations of lufenuron

resulted in the reduction of larval weight. Lufenuron also somewhat increased the larval period compared to control. Similar results are reported by Kostyukovsky et al. (2000) by exposing $T$. castaneum larvae to food medium treated with methoprene and pyriproxifen.

All the tested concentrations of lufenuron caused noteworthy reduction in oviposition in both strains of $T$. castaneum. At the concentration of $0.08 \mathrm{ppm}, 86.3$ and $86.8 \%$ reproductive control (PRC) was obtained in the ML and FD strains, respectively, compared to control (ANOVA, $\mathrm{df}=2, \mathrm{~F}=178.33 ; p<0.001$, Table 3). However, PRC was not significantly different between the strains (ANOVA, $\mathrm{df}=2, \mathrm{~F}=$ 2.12; $p>0.05$, Table 3 ). Hatching percentage of eggs was significantly reduced at all the concentrations. Egg sterility of 93.8 and $94.5 \%$ taken place at $0.08 \mathrm{ppm}$ in the ML and FD strains, respectively, compared to control (ANOVA, $\mathrm{df}=2$, $\mathrm{F}=155.00 ; p<0.001$, Table 3 ). The percentage of egg

TABLE 2. Effect of different concentrations of lufenuron on development of pupae and adults in T. castaneum

\begin{tabular}{cccc}
\hline Strain & $\begin{array}{c}\text { Concentration } \\
(\mathrm{ppm})\end{array}$ & $\begin{array}{c}\text { Mean } \pm \text { SE } \\
\text { pupae } \\
(\% \text { inhibition })^{\mathrm{a}}\end{array}$ & $\begin{array}{c}\text { Mean } \pm \text { SE } \\
\text { adults } \\
(\% \text { inhibition })^{\mathrm{b}}\end{array}$ \\
\hline ML & 0.08 & $7.66 \pm 0.33$ & $4.33 \pm 0.33$ \\
& $(55.8 \pm 1.92)$ & $(72.9 \pm 2.08)$ \\
& 0.04 & $9.33 \pm 0.33$ & $6.66 \pm 0.33$ \\
& 0.02 & $(46.1 \pm 1.92)$ & $(58.3 \pm 2.08)$ \\
& 0.00 & $13.00 \pm 0.57$ & $10.33 \pm 0.33$ \\
& & $(25.0 \pm 3.33)$ & $(35.4 \pm 2.08)$ \\
& 0.08 & $17.33 \pm 0.33$ & $16.00 \pm 0.57$ \\
& 0.04 & - & - \\
& 0.02 & $(58.5 \pm \pm 1.88)$ & $3.66 \pm 0.33$ \\
& & $8.66 \pm 0.33$ & $(77.5 \pm 2.04)$ \\
& 0.00 & $(50.9 \pm 1.88)$ & $6.33 \pm 0.66$ \\
& $12.66 \pm 0.33$ & $(61.2 \pm 4.08)$ \\
& $(28.3 \pm 1.88)$ & $10.00 \pm 0.57$ \\
& $17.66 \pm 0.33$ & $(38.8 \pm 3.53)$ \\
& - & $16.33 \pm 0.33$ \\
\end{tabular}

$\mathrm{a}=100 *(1-\mathrm{t} / \mathrm{c})$, where $\mathrm{t}$ is the number of pupae in treated flour, and $\mathrm{c}$ is the number of pupae in control, $\mathrm{b}=100 *(1-\mathrm{t} / \mathrm{c})$, where $\mathrm{t}$ is the number of adults in treated flour, and $\mathrm{c}$ is the number of adults in control 
sterility was not statistically different between the strains (ANOVA, $\mathrm{df}=2, \mathrm{~F}=1.92 ; p>0.05$, Table 3 ). Likewise, in the present study, when adults emerging from treated larvae were allowed to lay eggs, both egg laying and hatchability were reduced considerably. This outcome might be due to the transovarial activity of lufenuron that has caused reduction in egg laying and egg hatchability of the treated adults. Several authors have reported that adults emerged from CSI treated larvae or developed on treated food mostly produce fewer eggs compared to untreated adults (Elek 1998a; Parween et al. 2001; Qurban et al. 2016). Abo-Elghar et al. (2004) also reported the ovicidal and development inhibition activity of CSIs against cowpea weevil.

$\mathrm{F}_{1}$ larval development resulting from hatched eggs was reduced significantly at all the concentrations of lufenuron tested. A concentration of 0.08 ppm caused 96.2 and $97.1 \%$ $\mathrm{F}_{1}$ larvae inhibition compared to control treatment in the ML and FD strains, respectively (ANOVA, $\mathrm{df}=2, \mathrm{~F}=176.30$; $p<0.001$, Table 4). $\mathrm{F}_{1}$ pupae were inhibited by 97.5 and $98.6 \%$ at 0.08 ppm compared to control in the ML and FD strains, respectively, and this effect was significantly different at all the concentrations (ANOVA, $\mathrm{df}=2, \mathrm{~F}=220.68$; $p<0.001$, Table 4), but the inhibition in $\mathrm{F}_{1}$ pupae was not

TABLE 3. Oviposition and egg hatching in T. castaneum due to larval exposure to lufenuron

\begin{tabular}{cccc}
\hline Strain & $\begin{array}{c}\text { Concentration } \\
(\mathrm{ppm})\end{array}$ & $\begin{array}{c}\text { Mean } \pm \text { SE } \\
\text { eggs laid } \\
(\text { PRC })^{\mathrm{a}}\end{array}$ & $\begin{array}{c}\text { Mean } \pm \text { SE } \\
\text { eggs hatched } \\
(\% \text { Sterility })^{\mathrm{b}}\end{array}$ \\
\hline ML & 0.08 & $17.00 \pm 1.15$ & $6.66 \pm 0.66$ \\
& 0.04 & $(86.3 \pm 0.93)$ & $(93.8 \pm 0.61)$ \\
& 0.02 & $37.33 \pm 2.60$ & $20.00 \pm 1.52$ \\
& 0.00 & $(69.9 \pm 2.09)$ & $(81.5 \pm 1.41)$ \\
& $70.66 \pm 2.02$ & $41.00 \pm 1.73$ \\
& $(43.0 \pm 1.63)$ & $(62.2 \pm 1.59)$ \\
FD & $124.00 \pm 6.80$ & $108.33 \pm 4.09$ \\
& & - & - \\
& 0.08 & $17.33 \pm 1.76$ & $6.33 \pm 0.66$ \\
& 0.04 & $(86.8 \pm 1.34)$ & $(94.5 \pm 0.57)$ \\
& 0.02 & $35.00 \pm 3.21$ & $18.33 \pm 1.20$ \\
& 0.00 & $(73.3 \pm 2.45)$ & $(84.2 \pm 1.03)$ \\
& $(49.33 \pm 4.40$ & $40.7 \pm 3.52$ \\
& $131.00 \pm 5.13$ & $(64.8 \pm 3.04)$ \\
& & - & $115.67 \pm 5.69$ \\
\hline
\end{tabular}

$\mathrm{a}=100 *(1-\mathrm{t} / \mathrm{c})$, where $\mathrm{t}$ is the number of eggs laid by treated adults, and $\mathrm{c}$ is the number of eggs laid by untreated adults, $\mathrm{b}=100 *(1-\mathrm{t} / \mathrm{c})$, where $t$ is the number of eggs hatched in treated flour, and $c$ is the number of eggs hatched in control

TABLE 4. Development of $\mathrm{F}_{1}$ larvae, pupae and adults of T. castaneum due to larval exposure to lufenuron

\begin{tabular}{|c|c|c|c|c|}
\hline Strain & $\begin{array}{c}\text { Concentration } \\
(\mathrm{ppm})\end{array}$ & $\begin{array}{c}\text { Mean } \pm \mathrm{SE} \\
\mathrm{F}_{1} \text { larvae } \\
(\% \text { inhibition })^{\mathrm{a}}\end{array}$ & $\begin{array}{c}\text { Mean } \pm \mathrm{SE} \\
\mathrm{F}_{1} \text { pupation } \\
(\% \text { inhibition })^{\mathrm{b}}\end{array}$ & $\begin{array}{c}\text { Mean } \pm \mathrm{SE} \\
\mathrm{F}_{1} \text { adults } \\
(\% \text { inhibition })^{\mathrm{c}}\end{array}$ \\
\hline \multirow[t]{4}{*}{ ML } & 0.08 & $\begin{array}{c}3.66 \pm 0.33 \\
(96.2 \pm 0.34)\end{array}$ & $\begin{array}{c}2.33 \pm 0.33 \\
(97.5 \pm 0.36)\end{array}$ & $\begin{array}{c}0.66 \pm 0.33 \\
(99.2 \pm 0.39)\end{array}$ \\
\hline & 0.04 & $\begin{array}{l}12.66 \pm 0.88 \\
(86.9 \pm 0.90)\end{array}$ & $\begin{array}{l}10.66 \pm 0.88 \\
(88.4 \pm 0.96)\end{array}$ & $\begin{array}{c}7.00 \pm 0.57 \\
(91.8 \pm 0.67)\end{array}$ \\
\hline & 0.02 & $\begin{array}{l}31.66 \pm 1.45 \\
(67.4 \pm 1.49)\end{array}$ & $\begin{array}{l}28.66 \pm 0.88 \\
(68.7 \pm 0.96)\end{array}$ & $\begin{array}{l}21.33 \pm 0.66 \\
(75.0 \pm 0.78)\end{array}$ \\
\hline & 0.00 & $\begin{array}{c}97.00 \pm 5.50 \\
-\end{array}$ & $\begin{array}{c}91.66 \pm 5.20 \\
-\end{array}$ & $\begin{array}{c}85.33 \pm 4.66 \\
-\end{array}$ \\
\hline \multirow[t]{4}{*}{ FD } & 0.08 & $\begin{array}{c}3.00 \pm 0.57 \\
(97.1 \pm 0.55)\end{array}$ & $\begin{array}{c}1.33 \pm 0.66 \\
(98.6 \pm 0.67)\end{array}$ & $\begin{array}{c}0.33 \pm 0.33 \\
(99.6 \pm 0.36)\end{array}$ \\
\hline & 0.04 & $\begin{array}{l}11.66 \pm 0.88 \\
(88.7 \pm 0.85)\end{array}$ & $\begin{array}{c}9.33 \pm 0.66 \\
(90.5 \pm 0.67)\end{array}$ & $\begin{array}{c}6.00 \pm 0.57 \\
(93.5 \pm 0.62)\end{array}$ \\
\hline & 0.02 & $\begin{array}{l}31.33 \pm 2.90 \\
(69.8 \pm 2.80)\end{array}$ & $\begin{array}{l}28.66 \pm 2.60 \\
(70.9 \pm 2.63)\end{array}$ & $\begin{array}{l}21.00 \pm 2.08 \\
(77.3 \pm 2.25)\end{array}$ \\
\hline & 0.00 & $\begin{array}{c}103.67 \pm 3.28 \\
-\end{array}$ & $\begin{array}{c}98.66 \pm 3.28 \\
-\end{array}$ & $\begin{array}{c}92.33 \pm 3.33 \\
-\end{array}$ \\
\hline
\end{tabular}

$a=100 *(1-t / c)$, where $t$ is the number of larvae in treated flour, and $c$ is the number of larvae in control, $b=100 *(1-t / c)$, where $t$ is the number of pupae in treated flour, and $\mathrm{c}$ is the number of pupae in control and $\mathrm{c}=100 *(1-\mathrm{t} / \mathrm{c})$, where $\mathrm{t}$ is the number of adults in treated flour, and $\mathrm{c}$ is the number of adults in control 
significantly different between the strains (ANOVA, $\mathrm{df}=2$, $\mathrm{F}=2.75 ; p>0.05$, Table 4 ). Finally, at the concentration of $0.08 \mathrm{ppm}$, emergence of $\mathrm{F}_{1}$ adults was suppressed by 99.2 and $99.6 \%$ compared to control in the ML and FD strains, respectively. Inhibition of $F_{1}$ adult emergence was significantly different at each concentration $(\mathrm{F}=215.88 ; p$ $<0.001$, Table 4 ), but this effect was statistically similar in both strains (ANOVA, $\mathrm{df}=2, \mathrm{~F}=2.40 ; p>0.05$, Table 4). In this present experiment, the development of $F_{1}$ larvae, pupae and adults were all inhibited compared to control treatment. These results and those of others (Trostanetsky \& Kostyukovsky 2008) suggest that when adults of $T$. castaneum are treated with CSIs, these chemicals are taken up by adults that affect the subsequent development of offspring. This penetration of CSI might be due to contact or ingestion (Cutler et al. 2005; Kostyukovsky \& Trostanetsky 2006).

In view of these effects of lufenuron against $T$. castaneum, further studies are necessary to assess the residual effectiveness and persistence of lufenuron over prolonged period of time in mills, granaries and food storage facilities for the better replacement of generally used organophosphate and pyrethroid grain protectants.

\section{REFERENCES}

Abbott, W.S. 1925. A method of computing the effectiveness of an insecticide. Journal of Economic Entomology 18: 265-267.

Abo-Elghar, G.E.,El-Sheikh, A.E., El-Sayed,F.M., El-Maghraby, H.M. \& El-Zun, H.M. 2004. Persistence and residual activity of an organophosphate, pirimiphos-methyl, and three IGRs, hexaflumuron, teflubenzuron and pyriproxyfen, against the cowpea weevil, Callosobrushus maculates (Coleoptera: Bruchidae). Pest Management Science 60: 95-102.

Arthur, F.H. \& Hartzer, K.L. 2018. Susceptibility of selected stored product insects to a combination treatment of pyriproxyfen and novaluron. Journal of Pest Science 91: 699-705.

Arthur, F.H., Liu, S., Zhao, B. \& Phillips, T.W. 2009. Residual efficacy of pyriproxifen and hydroprene applied to wood, metal and concrete for control of stored-product insects. Pest Management Science 65: 791-797.

Bell, C.H. 2000. Fumigation in the 21st century. Crop Protection 19: 563-569.

Benhalima, H., Chaudhry, M.Q., Mills, K.A. \& Price, N.R. 2004. Phosphine resistance in stored product insects collected from various grain storage facilities in Morocco. Journal of Stored Products Research 40: 241-249.

Chaudhry, M.Q. 1997. A review of the mechanism involved in the action of phosphine as an insecticide and phosphine resistance in stored product insect. Pesticide Science 49: 213-228.

Cutler, G.C., Scott-Dupree, C.D., Tolman, J.H. \& Harris, C.R. 2005. Acute and sublethal toxicity of novaluron, a novel chitin synthesis inhibitor, to Leptinotarsadecem lineata (Coleoptera: Chrysomelidae). Pest Management Science 61: 1060-1068.

Daglish, G.J. \& Wallbank, B.E. 2005. Efficacy of diflubenzuron plus methoprene against Sitophilusoryzae and Rhyzoperthadominica in stored sorghum. Journal of Stored Products Research 41: 353-360.

El-Din, H.A.S., El-Samniand, M.A. \& Attia, M.B. 1990. Latent effect of certain insect growth regulators on body weight of the carniolan honeybee workers Apis mellifera L. (Hymenoptera: Apidae). Anz. Schädlingskd. Pfl. Umwelt 63: 67-68.

Elek, A. \& Longstaff, B.C. 1994. Effect of chitin-synthesis inhibitors on stored product beetles. Pesticide Science 40: 225-230.

Elek, J.A. 1998a. Treatment of adult coleoptera with a chitin synthesis inhibitor affects mortality and development time of their progeny. Entomologia Experimentalist Applicata 88: 31-39.

Elek, J.A. 1998b. Interaction of treatment of both adult and immature Coleoptera with a chitin synthesis inhibitor affects mortality and development time of their progeny. Entomologia Experimentalist Applicata 89: 125-136.

Ishaaya, I., Barazani, A., Kontsedalov, S. \& Horowitz, A.R. 2007.Insecticides with novel mode of action: Mechanism, selectivity and cross-resistance. Entomological Research 37: 148-152.

Kostyukovsky, M. \& Trostanetsky, A. 2006. The effect of a new chitin synthesis inhibitor, novaluron, on various developmental stages of Tribolium castaneum (Herbst). Journal of Stored Products Research 42: 136-148.

Kostyukovsky, M., Chen, B., Atsmi, S. \& Shaaya, E. 2000. Biological activity of two juvenoids and two ecdysteroids against three stored product insects. Insect Biochemistry and Molecular Biology 30: 891-897.

Malik, G., Qadir, A., Khan, H.A.A. \& Aslam, A. 2017. Toxicity of lufenuron and thiamethoxam against five Pakistani strains of Sitophilus oryzae on wheat, rice and maize. Pakistan Entomologist 39(1): 41-47.

Mishra, P.B., Salokhe, S.G. \& Deshpande, S.G. 2013. Biological and bio-chemical effects of lufenuron (IgR) on growth, development and reproduc-tive performance of Tribolium castaneum (Herbst) (Coleoptera: Tenebrionidae) (Adults). Research Journal of Pharmaceutical, Biological and Chemical Sciences 4: 802-810.

Mondal, K.A.M.S.H. \& Parween, S. 2001. Insect growth regulators and their potential in the management of storedproduct pests. Integrated Pest Manag. Rev. 5: 255-295.

Norman, K.N.T. 2000. The persistence of methyl bromide residues in rice, dried fruit, seeds and nuts following laboratory fumigation. Pest Management Science 56: 154158.

Oberlander, H., Silhacek, D.L., Shaaya, E. \& Ishaaya, I. 1997. Current status and futureperspectives of the use of insect growth regulators for the control of stored product pests. Journal of Stored Products Research 33(1): 1-6.

Parveen, F. 2000. Sublethal effects of chlorfluazuron on reproductivity and viability of Spodoptera litura (F.) (Lepidoptera:Noctuidae). Journal of Applied Entomology 124: 223-231.

Parween, S. 2003. Embryocidal and larvicidal effects of triflumuron against the red flour beetle, Tribolium castaneum (Herbst) (Coleoptera: Tenebrionidae). International Pest Control 45: 329-332.

Parween, S., Faruki, S.I. \& Begum, M. 2001. Impairment of reproduction in the red flour beetle, Tribolium castaneum(Herbst) (Coleoptera: Tenebrionidae) due to larval feeding on triflumuron-treated diet. Journal of Applied Entomology 125: 413-416.

Phillips, T.W. \& Throne, J.E. 2010. Biorational approaches to managing stored-product insects. Annual Review Entomology 55: 375-397. 
Qurban, A., Hasan, M., Sagheer, M., Saleem, S., Faisal, M., Naeem, A. \& Iqbal, J. 2017. Screening of seven insect growth regulators for their anti-insect activity against the larvae of Trogoderma granarium (Everts) and Tribolium castaneum (Herbst). Pakistan Journal of Agricultural Sciences 54(3): 589-595.

Qurban, A., Hasan, M., Mason, L.J., Sagheer, M. \& Javed, N. 2016. Biological activity of insect growth regulators, Pyriproxyfen, Lufenuron and Methoxyfenozide against Tribolium castaneum (Herbst). Pakistan Journal of Zoology 48(5): 1337-1342.

Sagheer, M., Yasir, M., Hasan, M. \& Ashfaq, M. 2012. Impact of triflumuron on reproduction and development of red flour beetle, Tribolium castaneum (Herbst) (coleoptera: tenebrionidae). Pakistan Journal of Agricultural Sciences 49(2): 173-178.

Sagheer, M., Yasir, M., Khan, B.S. \& Hasan, M. 2011. Ovicidal and reproduction inhibition activity of flufenoxuron, an acylurea insect growth regulator, against Tribolium castaneum (Herbst) (Coleoptera: Tenebrionidae). Pakistan Entomologist 33(2): 131-136.

Salokhe, S.G., Pal, J.K. \& Mukherjee, S.N. 2003. Effect of sublethal concentrations of flufenoxuron on growth, development and reproductive performance of Tribolium castaneum (Herbst) (Coleoptera: Tenebrionidae). Invertebrate Reproduction Development 43: 141-150.

Silver, P. 1994. Alternatives to methyl bromide sought. Pesticide News 24: 12-27.

Smagghe, G., Salem, H., Tirry, L. \& Degheele, D. 1996. Action of a novel insect growth regulator tebufenozide against different developmental stages of four stored product insects. Parasitica 52: 61-69.

Statistix, 8.1. 2003. User's Manual. Analytical Software: Tallahassee, Florida.

Trostanetsky, A., Kostyukovsky, M. \& Quinn, E. 2015. Transovarial effect of Novaluron on Tribolium castaneum (Coleoptera: Tenebrionidae) after termination of direct contact. Journal of Insect Science 15(1): 125.
Trostanetsky, A. \& Kostyukovsky, M. 2008. Note: Transovarial activity of the chitin synthesis inhibitor novaluron on egg hatch and subsequent development of larvae of Tribolium castaneum. Phytoparasitica 36: 38-41.

Yasir, M., Sagheer, M., Hasan, M., Abbas, S.K. \& Ahmad, S. 2012. Bioactivity of a chitin synthesis inhibitor, triflumuron, against red flour beetle, Tribolium castaneum (Herbst) (Coleoptera: Tenebrionidae). Sarhad Journal of Agriculture 28(4): 603-609.

Muhammad Yasir

Pest Warning and Quality Control of Pesticides

Punjab, Lahore

Pakistan

Muhammad Yasir, Muhammad Sagheer \& Mansoor-ul-Hasan Department of Entomology

University of Agriculture, Faisalabad

Pakistan

Saqi Kosar Abbas \& Muhammad Ijaz*

College of Agriculture, BZU

Bahadur Sub Campus Layyah, Punjab

Pakistan

Saeed Ahmad

Sericulture Forest Department, Punjab

Pakistan

*Corresponding author; email: muhammad.ijaz@bzu.edu.pk

Received: 22 December 2016

Accepted: 21 March 2018 